\title{
Exploring the geographical distribution of wealth using the output area classification
}

\author{
Ellis Daniel and Geoff Bright \\ Office for National Statistics
}

\section{Summary}

The results of the first wave of the Wealth and Assets Survey were published in the report, 'Wealth in Great Britain' in December 2009 with datasets released in March 2010. However, apart from the presentation of the aggregate results on a Government Office Region basis, no more disaggregated geographical analysis of the data has so far been carried out, not least because of the potential disclosivity of the data when presented for low level geographies. This paper aims to provide an understanding of the geographical distribution of wealth and its components by areas with common socio-economic and demographic characteristics from relatively high to low levels of aggregation while overcoming the disclosivity problem. This is achieved by using the Output Area Classification (OAC) groupings, based on the 2001 Census.

\section{Introduction}

The Wealth and Assets Survey (WAS) commenced its first, two-year wave in July 2006, and gathered responses from a sample of approximately 30,000 private households from across Britain ${ }^{1}$. Information was collected at both at household and personal level on the property, physical $^{2}$, financial and pension wealth and indebtedness as well as attitudinal aspects and classificatory data. Although the second wave of the survey was completed in June 2010, and the third wave is now underway, data have only been released for wave 1 , so it is on these that the article will focus.

The Output Area Classification (OAC) taxonomy was devised as a means of presenting Census outputs for areas exhibiting common characteristics. First published in 2005 (Vickers et al, 2005) based on average values (proportions) for 41 demographic, housing and socio-economic Census outputs, OAC areas are first divided into seven clusters or 'supergroups' termed by Vickers et al 
(2005), 'blue collar', city living', 'countryside', 'prospering suburbs', 'constrained by circumstances' 'typical traits' and 'multicultural'. As Table 1 and Annex 1 indicate, these supergroups are next split into 21 groups (such as, 'terraced blue collar', 'younger blue collar', 'transient communities', 'accessible countryside'...) and further subdivided into 52 subgroups. An example of the geographical distribution of these groupings is illustrated in Map 1.

\section{Table $1 \quad$ OAC hierachy ${ }^{1}$}

\section{OAC Supergroup and Label}

1 - Blue Collar Communities

4 - Prospering suburbs

5 - Constrained by circumstances
6 - Typical traits

7 - Multicultural

2 - City Living

3 - Countryside

Note

\section{OAC Group and Label}

1a - Terraced blue collar

$1 \mathrm{~b}$ - Younger blue collar

1c - Older blue collar

2a - Transient communities

$2 b$ - Settled in the city

3a - Village life

$3 b$ - Agricultural

3c - Accessible countryside

$4 a$ - Prospering younger families

$4 \mathrm{~b}$ - Prospering older families

4c - Prospering semis

$4 d$ - Thriving suburbs

5 a - Senior Communities

$5 b$ - Older Workers

$5 c$ - Public Housing

$6 a$ - Settled households

$6 b$ - Least divergent

$6 c$ - Young families in terraced homes

$6 \mathrm{~d}$ - Aspiring households

7a - Asian communities

7b - Afro-Caribbean communities

1. OAC subgroups were not named

An introduction to OAC has been published by Vickers and Rees (2006). Populations of the OAC supergroups as well as an explanation of the cluster summaries can be found in Williams and Botterill (2006). Readers should be aware that names attached to the OAC supergroups (1 to 7 ) and groups (1a to $7 \mathrm{~b}$ ) are not part of the National Statistics Classification and should be used in conjunction with the cluster summaries provided by ONS (Vickers and Rees, 2006; ONS 2005). 


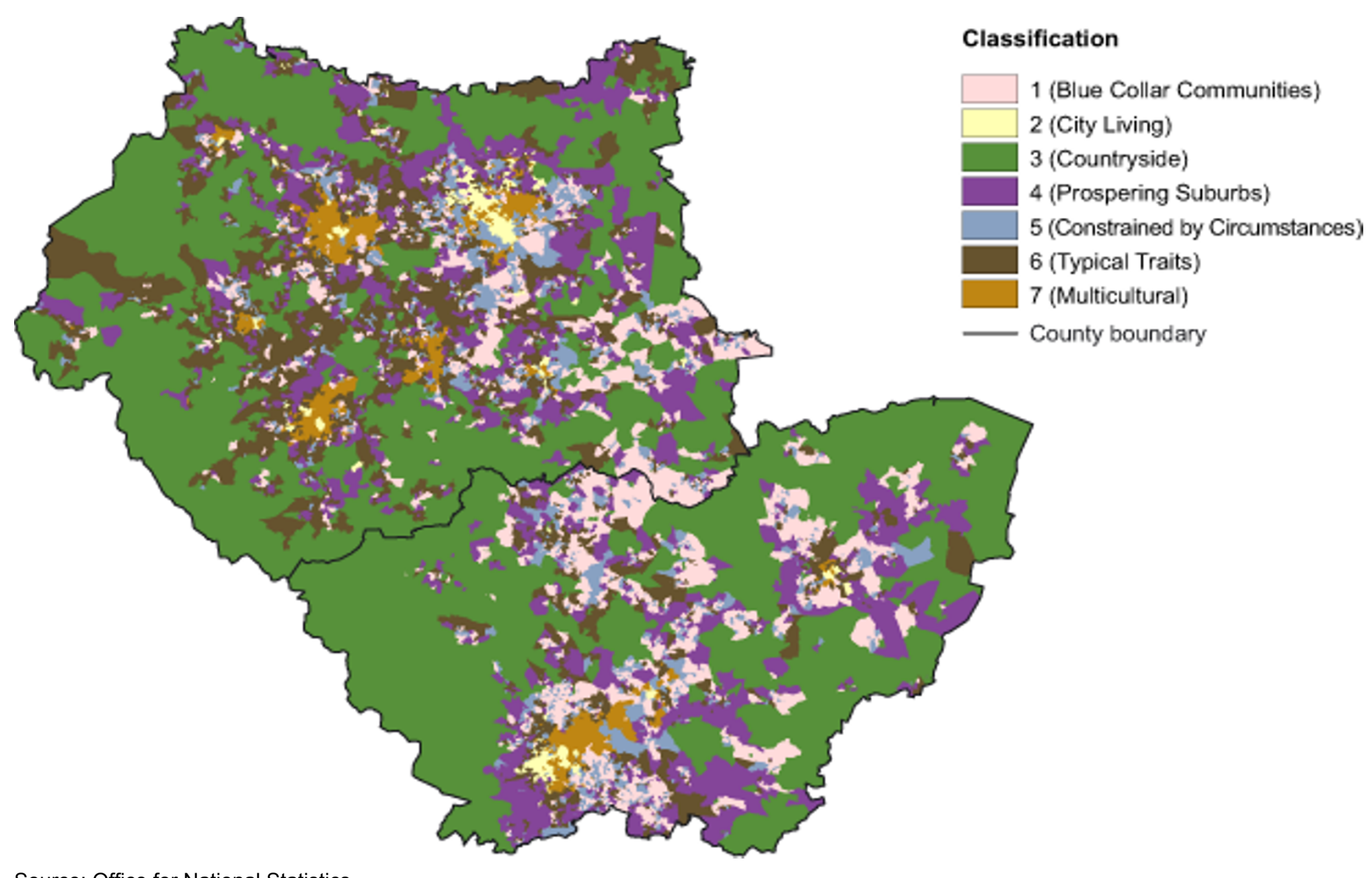

Source: Office for National Statistics 
The report, 'Wealth in Great Britain' (ONS, 2009), estimated that total wealth in Great Britain for the period 2006-2008 was $£ 9.0$ trillion with net property wealth and private pension wealth each accounting for 39 per cent of total wealth and net financial wealth and physical wealth 11 per cent each. However, the distribution of wealth, in all four categories, was shown to be highly skewed. Thus, although mean total household wealth (including private pension wealth) was calculated to be $£ 367,000,50$ per cent of households had total wealth of less than $£ 200,000$ while the most wealthy 5 per cent held wealth in excess of $£ 1.1$ million (Table 2 and Figure 1). Because of this skewness, any one measure of central tendency of the data is inadequate and even misleading so in such circumstances, the form of the distribution of the data must be borne in mind.

\section{Table $2 \quad$ Wealth by component}

\begin{tabular}{lccccc}
\hline & Property Wealth Pension Wealth & $\begin{array}{c}\text { Financial } \\
\text { Wealth }\end{array}$ & Physical Wealth $^{\mathbf{1}}$ & Total Wealth $^{1}$ \\
\hline Weighted Households & $24,583,701$ & $24,583,701$ & $24,583,701$ & $13,901,282$ & $13,901,282$ \\
Mean & $£ 143,214$ & $£ 141,890$ & $£ 39,432$ & $£ 39,666$ & $£ 367,125$ \\
Median & $£ 95,000$ & $£ 29,145$ & $£ 5,140$ & $£ 29,900$ & $£ 204,607$ \\
\hline
\end{tabular}

Source: Wealth and Assets Survey

1. Refers to the half sample only

\section{Figure 1 Total Wealth distribution}

Households (1,000s)

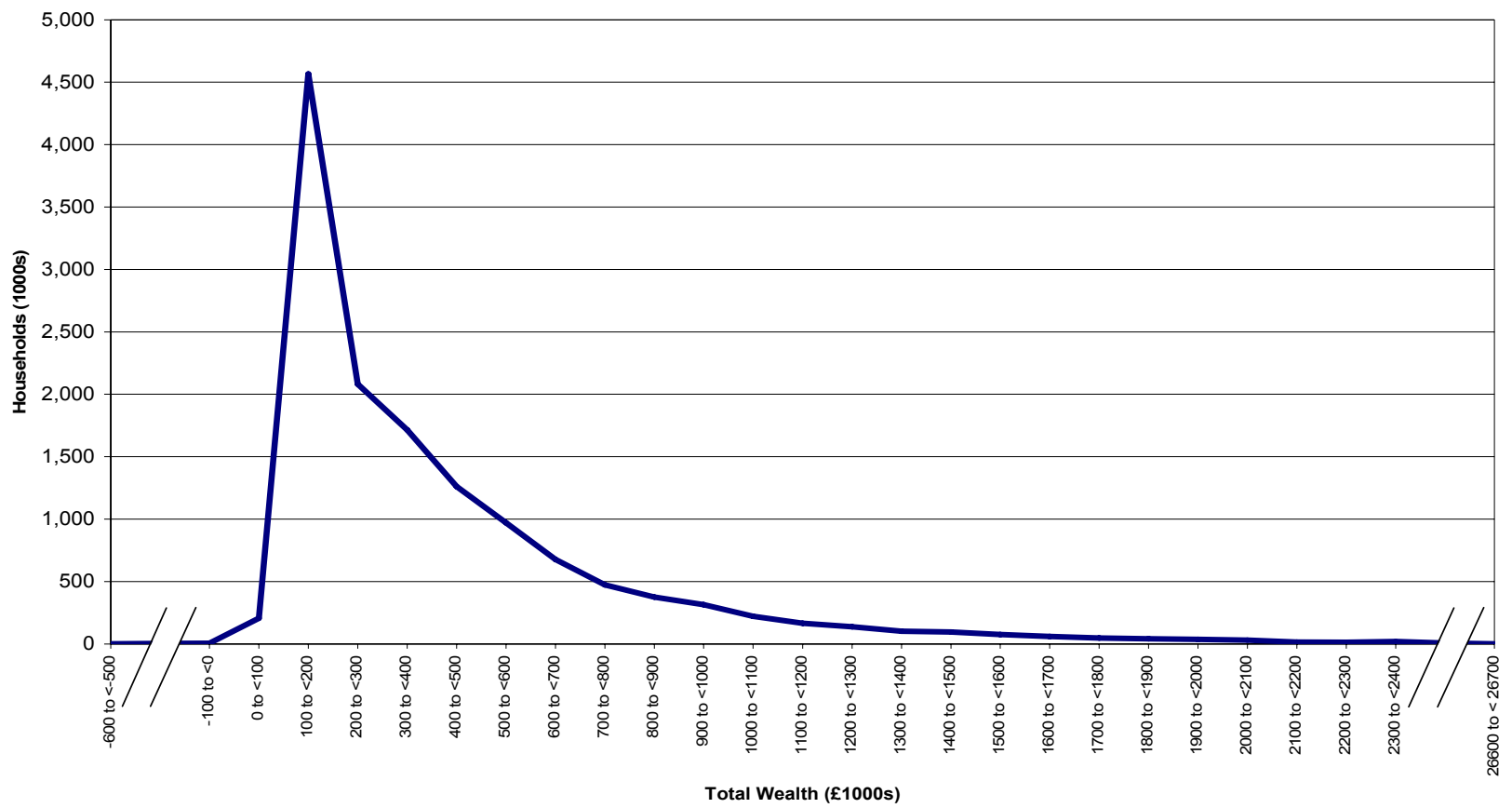

Source: Wealth and Assets Survey 
When considering the geographical distribution of wealth it is important to appreciate the multiplicity of underlying factors which determine or are at least associated with wealth. As the report shows, wealth varies over the lifecycle, rising as savings and entitlements are built up, to a peak for those in the 55-64 age-group, and falling thereafter as wealth is drawn upon or distributed. As Figure 2 shows, this pattern is repeated at supergroup level, with rankings remaining more or less the same over the life-cycle. Wealth also varies by household type, household structure, economic activity and socio-economic status. Thus, on the latter, across Britain the median total wealth ranges from $£ 532,500$ for household reference persons classified in the 'large employers and higher managerial' group to $£ 15,000$ for those in the 'never worked/longterm unemployed' group (ONS, 2009).

The OAC categories do, in fact, take account of many of the socio-economic and demographic differences, and these groupings represent clusters of households having certain of these characteristics in common, but differing significantly from other groups. This does not mean, however, that there are not overlaps between categories and variations within them. Neither does it mean that all of the underlying determinants and characteristics are covered by OA classifications. Nevertheless, analysing the extent to which mean and median values for supergroups, groups and subgroups diverge or converge does help in understanding some of the underlying factors associated with the geographical distribution of wealth.

\section{Figure 2 Wealth by age of household head 2006/08}

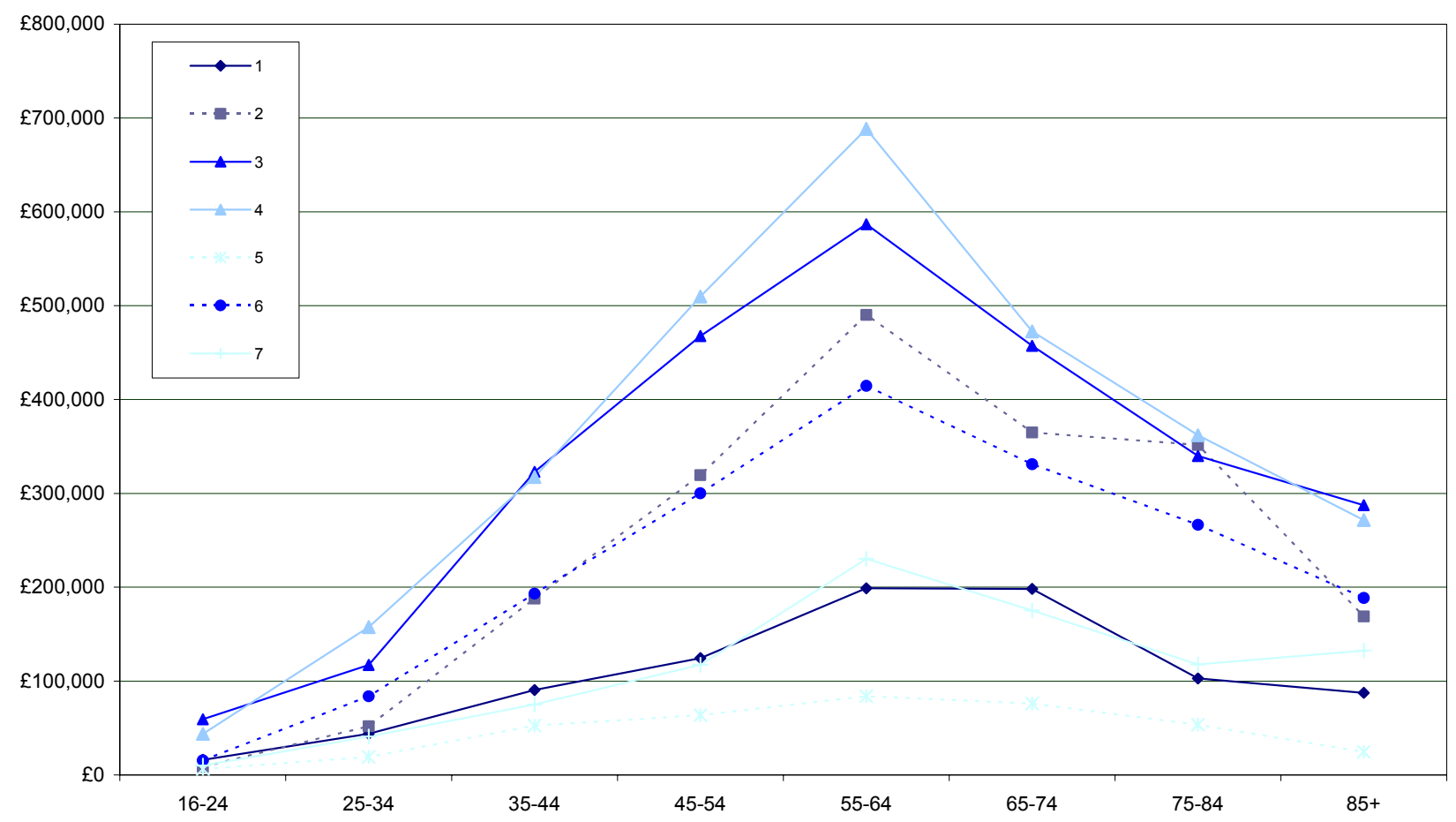

Source: Wealth and Assets Survey 
The article proceeds by discussing the OAC-based distribution of each wealth category - property, pension, financial and physical as well as total wealth ${ }^{3}$, for supergroups, groups and subgroups, compares the patterns for each of these wealth types and then draws conclusions regarding the wealth distribution patterns and the use of OAC for such studies.

As mentioned previously, means and medians are referred to in the discussion that follows; readers may refer to the Annexes for values for each of the groupings. Standard errors of the means for each of the wealth categories are also been presented in Annex 2. Although the standard error calculations have taken account of some of the nuances of the survey design, they have not done so completely, so they should be used to provide an indication only.

\section{Property Wealth}

Mean property wealth at all levels of OAC depends not only on the value of properties, but the proportion of households owning property. Cluster summaries of OAC provide an insight into some of the factors that may contribute to mean property wealth. For example, the supergroup with proportions of public rented tenancy far above the national average ${ }^{4}$ are 1,5 and 7 (ONS, 2005), while those with proportions of privately rented tenants far above the national average are supergroups 2 and 7 . Other variables in the OAC clusters that may be associated with variations in property wealth are: Terraced Housing, Detached Housing and All Flats which each relate to the percentage of households of that size and type in an OAC cluster summary.

Mean net property wealth was highest in supergroup 3 at $£ 258,182$ and 4 at $£ 223,443^{5}$ while the lowest was in supergroups 1 at $£ 63,037$ and 5 at $£ 43,806$. All supergroups had positive mean net property wealth with groups 2,6 and 7 lying between the highest and lowest supergroups. Supergroups 3 and 4 exhibit highest values for median property wealth: $£ 188,000$ and $£ 180,000$ respectively. This contrasts with the zero median property wealth of supergroups 5 and 7 .

At group level, supergroups 3 and 4 tend to include those with higher values for mean and median property wealth but there are exceptions: 4c, with a mean of $£ 160,445$, is lower than $6 \mathrm{~d}, £ 204,414$. The lowest group means are found mostly in supergroups 1,5 and 7. At supergroup level, the median reveals some categories with zero property wealth, namely groups $1 \mathrm{a}, 5 \mathrm{a}, 5 \mathrm{~b}, 5 \mathrm{c}$ and $7 \mathrm{~b}$. There was also very low median property wealth in $1 b, £ 11,700$ and $2 a, £ 5,000$. All of these groups have relatively high proportions of renting households with either flats or terraced housing being predominant.

As Figure 3 shows, mean property wealth at subgroup level tends to reflect the distribution at group and supergroup level. The highest values are in the 3 and 4 supergroups with $3 b 1,3 b 2$, $3 \mathrm{c} 2,4 \mathrm{~b} 3$ and $4 \mathrm{~d} 1$ having the highest mean property wealth. Just over half of the subgroups had property wealth above the average for Great Britain: but apart from all subgroups belonging to supergroup 3 and 4 (except 4c1 which was below average), only 2a2, 2b1, 2b2, 6b2, 6d1, 6d2 and $7 a 3$ meet this criterion. All subgroups within supergroups 1, 5 and 7 (except $7 a 3$ ) fall well below the mean. 


\section{Figure 3 Property Wealth by OAC groups, 2006/08}

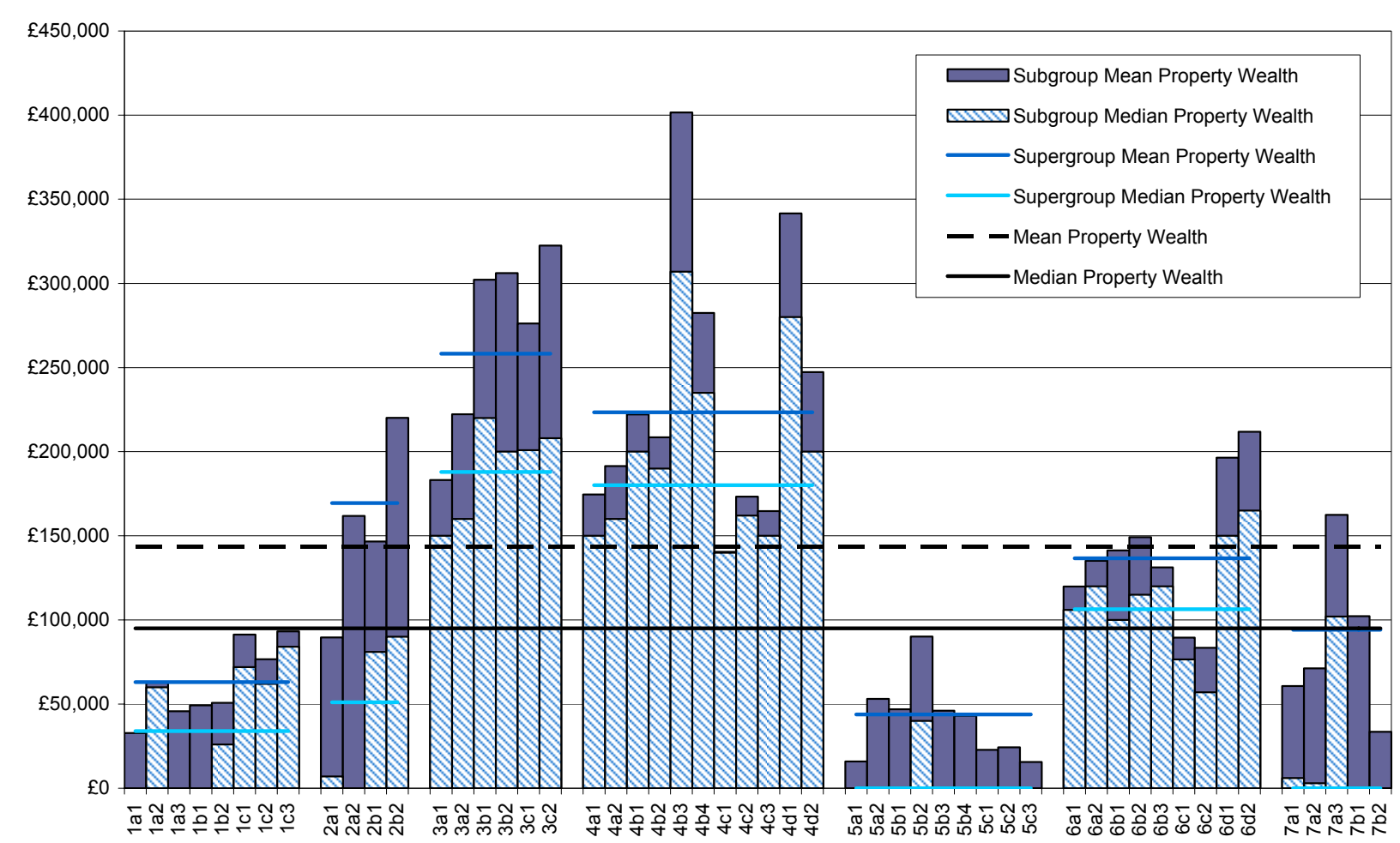

Source: Wealth and Assets Survey

Median property wealth at subgroup level reveals the wide variation in values, not only between subgroups belonging to different supergroups but also between subgroups within the same supergroup. $5 \mathrm{~b} 2$ had a median of $£ 40,000$ but was the only subgroup within supergroup 5 that did not have zero median property wealth. Similarly, $7 a 3$ had median property wealth of $£ 102,000$ but the other subgroups in supergroup 7 had very low or zero property wealth. In all, 14 subgroups had zero median property wealth, whereas all subgroups within supergroups 3 and 4 had such wealth in excess of $£ 150,000$.

\section{Pension Wealth}

'Wealth in Great Britain' reported differences in levels of pension wealth by some of the characteristics that were used to develop OAC cluster summaries. Pension wealth tended to be highest in households whose household reference person (HRP) was educated to degree level or above, aged 55-64, married/cohabiting and owning the property (ONS, 2009). As detailed before, supergroups 1, 5 and 7 have high proportions of tenants, while the first two are well below the national average for the variable Higher Education (HE) Qualification.

The mean pension wealth was highest for supergroups 3 at $£ 224,241$ and 4 at $£ 237,058$. This was also true for the medians of 3 and 4 which were $£ 68,631$ and $£ 103,772$ respectively. The lowest mean pension wealth was in supergroups 1,5 and 7 - ranging from $£ 60,128$ in 5 to $£ 70,443$ in 7 , and only the first of these has a median substantially greater than zero. 
Examining pension wealth by OAC group gives a similar picture to that at supergroup level, but with a few exceptions. Mean pension wealth was generally highest in the groups within supergroups 3 and 4, lowest for 1, 5 and 7 , with 2 and 6 in between. $6 \mathrm{~d}$ - which has low proportions of publicly rented tenants - is noteworthy as it had a reasonably high level of mean pension wealth at $£ 203,004$. Group $4 \mathrm{c}$ also breaks from other groups within supergroup 4 with a mean of $£ 170,307$, close to the mean of $£ 169,819$ for $2 b$.

As Figure 4 shows, high values for pension wealth subgroups were mostly concentrated in those belonging to the 3 and 4 supergroups with $4 \mathrm{~b} 3$ having the highest mean and median: $£ 359,356$ and $£ 200,671$. 4b3 has characteristics which may explain the high level of pension wealth - above average proportions of workers in the finance industry and persons with a degree level education, comparatively older HRP's, as well as low proportions of tenants and the unemployed. Subgroups of supergroups 1, 5 and 7 exhibit the lower pension wealth means. In particular subgroups $5 \mathrm{c} 3$, $7 \mathrm{a} 1$ and $5 \mathrm{c} 2$ had low mean pension wealth at $£ 17,257, £ 27,429$ and $£ 29,130$ as well as zero median pension wealth. 5a1, 5c1 and $7 \mathrm{~b} 2$ also had zero median pension wealth. These six subgroups contain high proportions of tenants (some private, some public or both) and some have high proportions of lone parents, students, the unemployed and economically inactive.

\section{Figure 4 Pension Wealth by OAC groups, 2006/08}

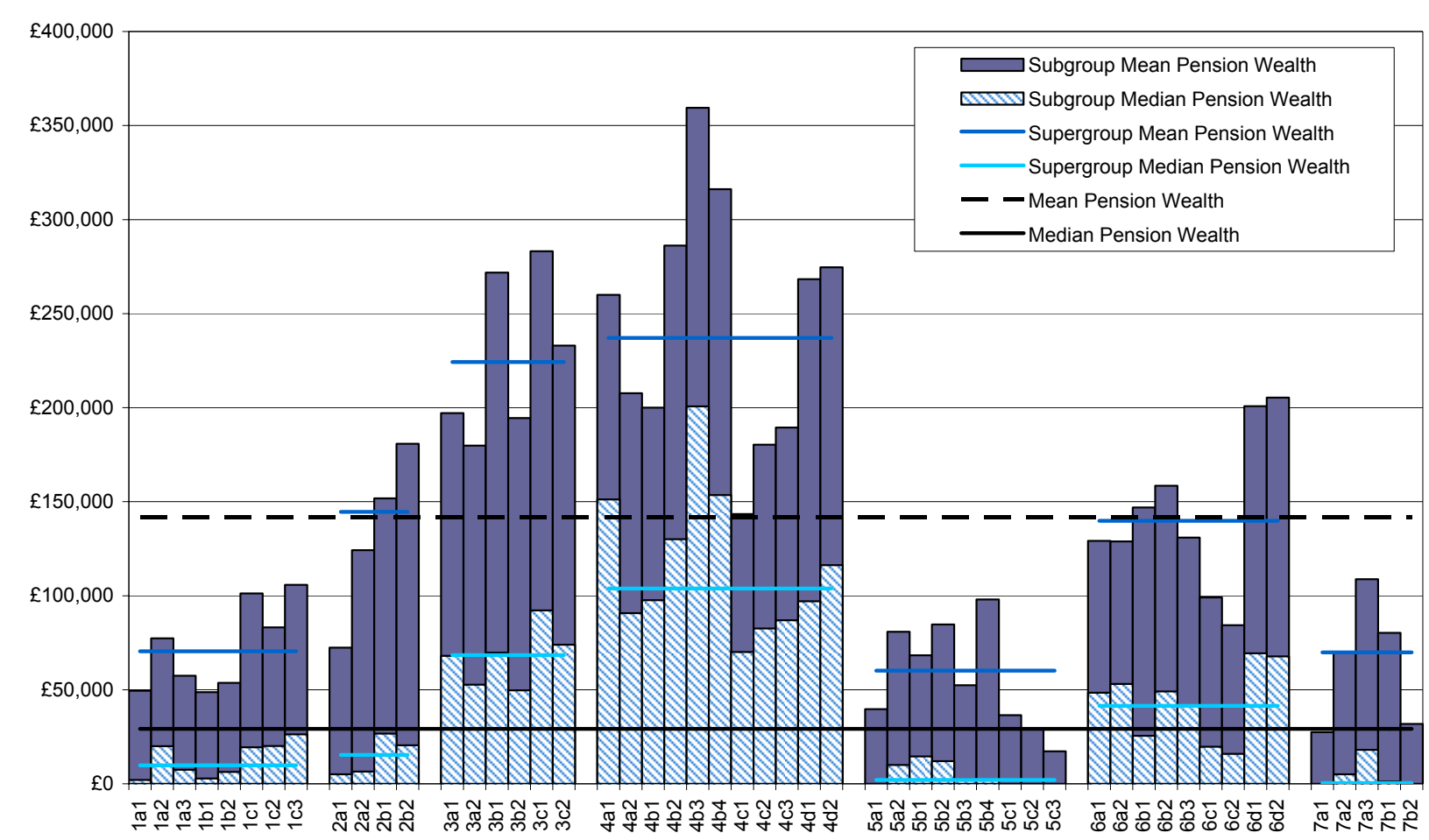

Source: Wealth and Assets Survey

More than half of the subgroups had pension wealth below the national average: from 88 per cent below in $5 \mathrm{c} 3$ to 8 per cent below in $6 \mathrm{~b} 3$. Of those with above average pension wealth, this ranges from 1 per cent above in 4c1 up to 153 per cent above in 4b3. All subgroups belonging to supergroups 1, 5 and 7 are below the national average. 


\section{Financial Wealth}

As indicated in Table 2, the mean net financial wealth in Great Britain was $£ 39,432$ in 2006/08 whereas the median was $£ 5,140$. At the OAC supergroup level, mean financial wealth was highest in supergroups 3 and 4 which were 92 per cent and 71 per cent respectively above the mean for Great Britain. These supergroups also had the highest median financial wealth but with the order reversed: supergroup 4 having a median of $£ 24,200$ and supergroup $3, £ 18,750$.

Supergroups 5 and 1 had the lowest mean financial wealth: $£ 10,454$ and $£ 13,059$ respectively, constituting only 27 per cent and 33 per cent of the overall mean. The medians for these two supergroups as well as supergroup 7 are extremely low: less than $£ 1,000$ in all cases. Between these upper and lower classes are supergroup 2 with mean and median values of $£ 48,561$ and $£ 6,045$ and also supergroup 6 whose mean and median was $£ 34,976$ and $£ 6,900$.

At the OAC group level, the highest mean and median groups tend to come from the wealthiest supergroups ( 3 and 4 ), but groups $2 \mathrm{~b}$ and $6 \mathrm{~d}$ also had relatively high average financial wealth at $£ 54,645$ and $£ 58,226$ respectively.

Similarly, many, but not all, of the lowest financial wealth groups are encompassed by supergroups 1 and 5 . However, the groups with labels indicating them as 'older' tended to have somewhat higher wealth.

\section{Figure 5 Financial Wealth by OAC groups, 2006/08}

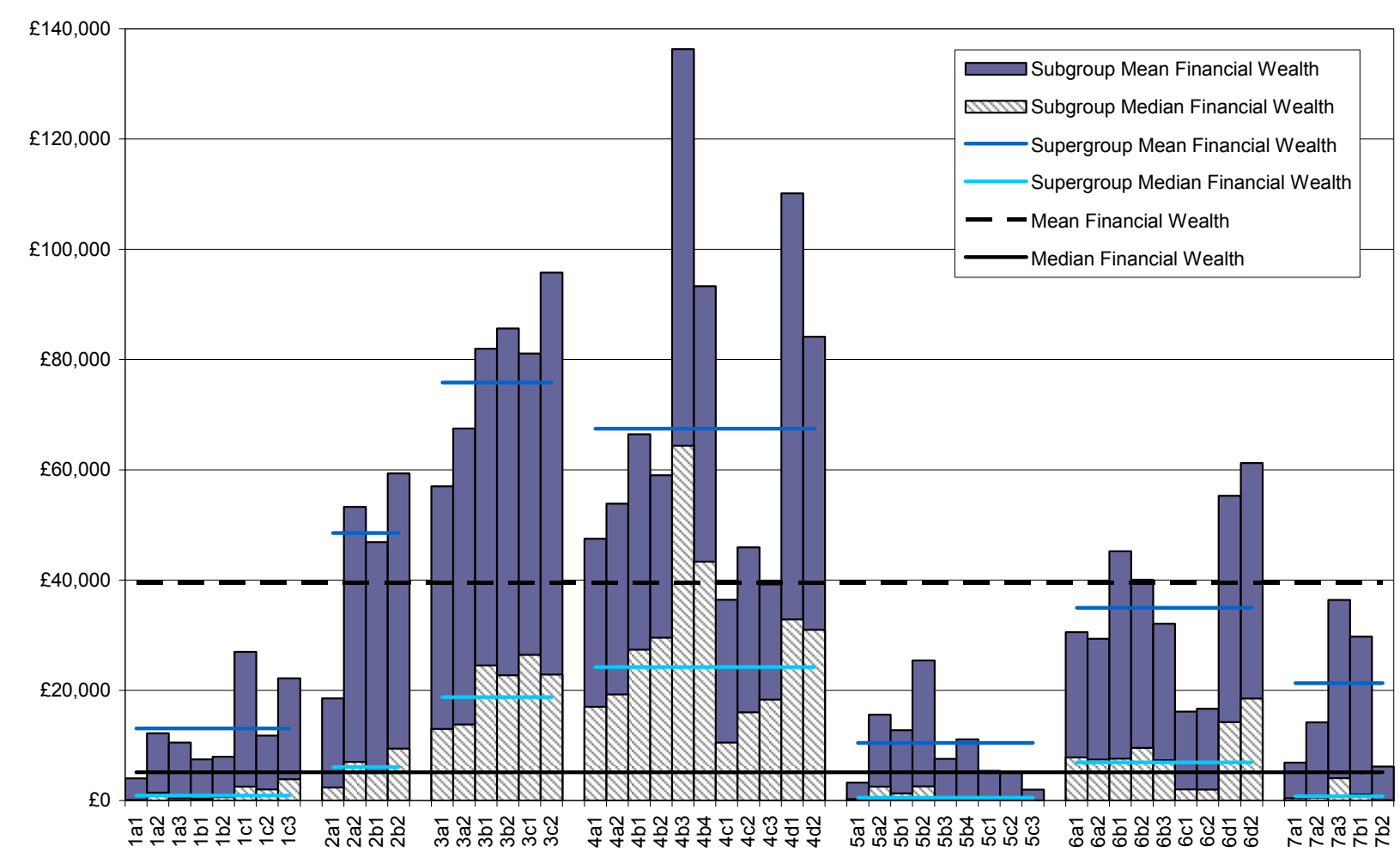

Source: Wealth and Assets Survey 
Figure 5 shows that there are noticeable differences in the level of financial wealth at supergroup level, but subgroups show more extremes. Supergroups 3 and 4 again contained the highest mean financial wealth subgroups. However, supergroup 4 exhibits some extremes in the subgroups as $4 \mathrm{~b} 3$ had very high mean financial wealth, $£ 136,336$, while $4 \mathrm{c} 1$ was much lower at $£ 36,411$ around the same level as some of the subgroups from supergroups 6 and 7 . Nevertheless, most subgroups had median financial wealth that was fairly close to the median of the supergroup, although for $4 \mathrm{c} 1$, the median of $£ 10,500$ remains the exception in supergroup 4 . At the other extreme, $4 b 3, £ 64,370$ was well above the median for the supergroup.

All of the subgroups within supergroups 1 and 7 , as well as most of those within 5 and 6 as along with $4 \mathrm{c} 1$ and $4 \mathrm{c} 3$ had financial wealth means below the national average.

\section{Physical Wealth}

Physical wealth is made up of the contents of the main residence of a household and of any other property which the household owns, collectables, valuables, vehicles and personalised number plates (ONS, 2009). For households which owned a vehicle ${ }^{6}$, the 'Wealth in Great Britain' report indicated that vehicles and personal number plates account for about 16 per cent of household physical wealth (ONS 2009).

The size and value of a specific property and of properties common to a location/area are likely to influence levels of physical wealth. Larger properties would be expected to hold more contents and thus, ceteris paribus, tend to have higher physical wealth. It should be also considered whether: households owning expensive properties are likely to hold higher value collectables such as antiques; city dwellers less likely to own vehicles such as cars; tenants are likely to report lower values for contents if they rent furnished accommodation. The answers to these may seem obvious but would be better supported by more detailed analysis not covered in this paper.

Car ownership is at present in the variables of OAC as ' $2+$ Car household' and this may be a contributing factor to higher levels of average physical wealth depending on the proportion of this variable in an area. OAC supergroups 3 and 4 are far above average for this variable while supergroup 5 is far below.

Mean physical wealth was the highest in supergroups 3 and 4 at $£ 56,861$ and $£ 53,145$ respectively. Median values were also highest in 3 and 4 at $£ 44,700$ and $£ 44,500$. There was not a great difference in the physical wealth held by the other five supergroups (Figure 6). Means ranged from $£ 25,124$ in 5 to $£ 39,037$ in 6 while median physical wealth showed a similar distribution: $£ 15,500$ in 5 to $£ 31,900$ in 6 . Supergroups 3 and 4 are the only categories which had above-average physical wealth although supergroup 6 is just below the average.

At group level, the distribution of physical wealth compared to the national average remains generally the same as at supergroup level.

The highest mean physical wealth in subgroups belonged to $4 \mathrm{~b} 3$ at $£ 74,067$, followed by $3 \mathrm{c} 2$ at $£ 68,319$ and $3 b 1$ at $£ 67,965$. The extra detail at the lowest level of OAC shows some subgroups 
diverging from their group or supergroup: $5 \mathrm{~b} 2$ had a mean of $£ 38,128$, much higher than others in supergroup 5 and the same can be said of $7 a 3$, with $£ 36,070$.

The median physical wealth was lowest in $5 c 3$ at $£ 10,500$ and highest in $4 b 3$ at $£ 55,500$. For all of the other three components of total wealth - financial, property, pension - at OAC subgroup level, some categories have medians of zero. However, this is not the case for physical wealth as for the other types of wealth it would be much more feasible for a household to have no wealth either by not having financial wealth, not owning a property, or not having a pension. Physical wealth refers to material possessions and more households had at least some wealth of this type. Furthermore, financial and property wealth may be zero in many instances because liabilities cancel out assets leaving zero net wealth for those types.

\section{Figure 6 Physical Wealth by OAC groups, 2006/08}

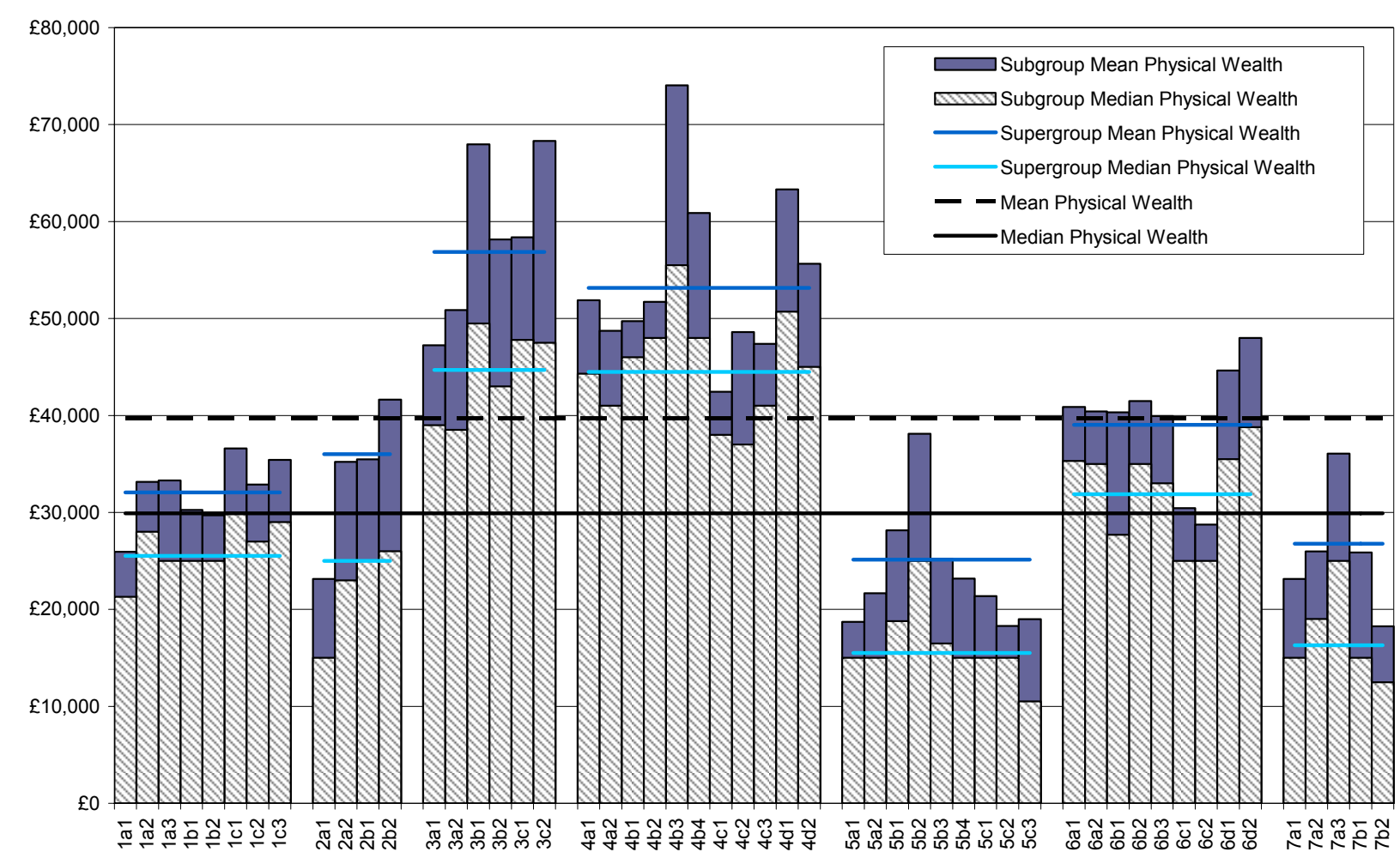

Source: Wealth and Assets Survey

\section{Total Wealth}

All OAC supergroups had positive mean and median net total wealth. The wealthiest OAC supergroups were 3 and 4 with mean wealth of $£ 622,271$ and $£ 576,748$ and median wealth of $£ 386,242$ and $£ 420,839$ respectively. The least wealthy supergroups are 5, 1 and 7 with mean wealth ranging from $£ 135,526$ to $£ 212,694$ and median wealth ranging from $£ 44,379$ to $£ 104,400$. The mean wealth in supergroup $2, £ 388,722$ was higher than $6, £ 349,400$, but the median in 2 , $£ 146,375$, was substantially lower than the median of $£ 223,770$ in supergroup 6 . 
Groups 3b, 3c, 4b and 4d are extremely wealthy with means of: $£ 694,364, £ 748,910, £ 713,978$ and $£ 732,586$, perhaps reflecting, inter alia, older HRP's and more expensive housing. The net wealth of these groups was up to 104 per cent above the national average. 3a, 4a, and 4c stand out as groups which are noticeably lower than others in the wealthiest supergroups with means of $£ 484,549, £ 529,607$ and $£ 414,573$ respectively. Households in $4 a$ tend to be younger as this subgroup has well below average proportions of persons aged over 65 , whereas this variable was close to average for supergroup 4.

Groups in supergroups 1, 5 and 7 are the least wealthy with $5 \mathrm{c}$ standing out as having the lowest mean, $£ 68,509$ and median, $£ 20,595.5 \mathrm{c}$ has high proportions of lone parent households and low proportions of persons qualified to degree level and, as 'Wealth in Great Britain' reported, the lowest mean and median total wealth was held by lone parent households with dependent children whereas those headed by a person educated to degree level or above were the wealthiest (ONS, 2009).

As has been seen with the components of wealth, total wealth remains highest in the subgroups belonging to supergroups 3 and 4 , with the $4 \mathrm{~b} 3$ mean exceeding $£ 1$ million (Figure 7). However, some of these subgroups (such as $4 \mathrm{a} 2,4 \mathrm{~b} 1$ and $4 \mathrm{c} 1$ ) did have mean wealth that was a good deal closer to the national average.

\section{Figure 7 Total Wealth by OAC groups, 2006/08}

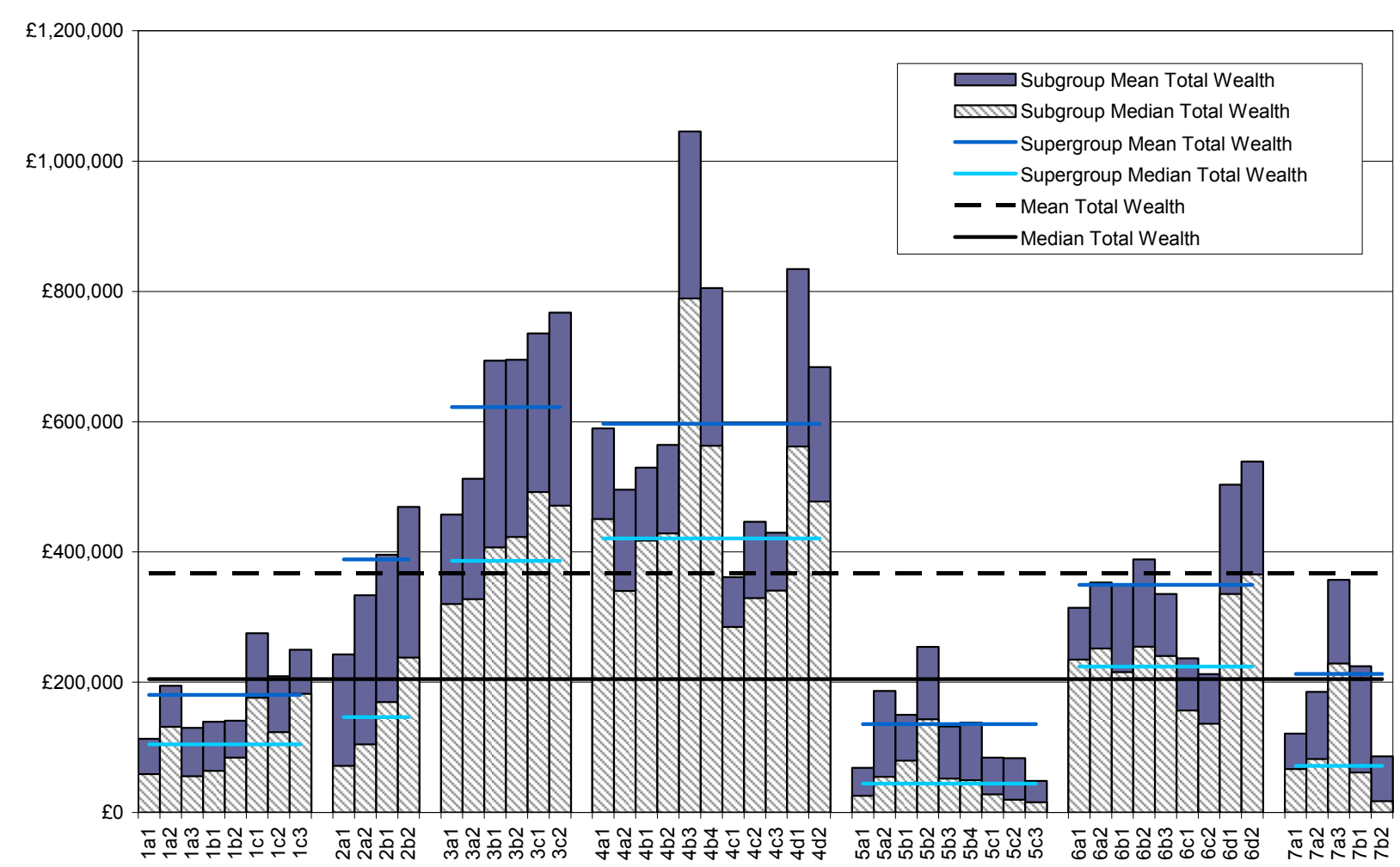

Source: Wealth and Assets Survey 
Subgroups show massive differences in mean wealth holdings across output areas. These large differences exist within categories as well: in supergroup 4, for instance, $4 \mathrm{~b} 3$ had the most wealth of all the subgroups and was 185 per cent above the mean yet $4 \mathrm{c} 1$, within the same supergroup, was just below the national average. On the other hand supergroups 1 and 5 show consistently low wealth at subgroup level.

\section{Relationship between wealth components}

As might be expected, the ranks of subgroups for each of the four wealth types and for total wealth are similar, with the Spearman's rank correlation coefficients all very close to 1 (Table 3 ).

Ranking the wealth components reveals the differences between the rank of a component in relation to that subgroup's total wealth rank. Some subgroups tend to rank higher or lower in terms of specific wealth types than their overall wealth rank would suggest, thus for physical wealth 1a3 and 2a1 are both 13 ranks apart from their total wealth rank, but in opposite directions: negative for $1 \mathrm{a} 3$ and positive for 2a1. Similarly, for pension wealth, $3 \mathrm{~b} 2$ was 9 ranks higher than its total wealth position and $5 \mathrm{~b} 4$ was 11 ranks lower. In terms of financial wealth, the two subgroups that stand out are $2 \mathrm{a} 2$ for being 10 ranks lower, and $4 \mathrm{a} 1$ for being 9 ranks higher than their total wealth ranks. $4 \mathrm{a} 1$ had property wealth that was 8 ranks higher than its total wealth; while subgroup 2a2 is 6 ranks lower than its total wealth rank.

\section{Table 3 Spearman's rank correlations between wealth components}

\begin{tabular}{|c|c|c|c|c|c|c|}
\hline $\mathrm{N}=52$ & & $\begin{array}{l}\text { Property } \\
\text { Wealth }\end{array}$ & $\begin{array}{l}\text { Pension } \\
\text { Wealth }\end{array}$ & $\begin{array}{l}\text { Financial } \\
\text { Wealth }\end{array}$ & $\begin{array}{l}\text { Physical } \\
\text { Wealth }\end{array}$ & $\begin{array}{c}\text { Total } \\
\text { Wealth }\end{array}$ \\
\hline \multirow[t]{2}{*}{ Property Wealth } & Correlation Coefficient & 1.00 & & & & \\
\hline & Sig. (2-tailed) & . & & & & \\
\hline \multirow[t]{2}{*}{ Pension Wealth } & Correlation Coefficient & $0.94^{* *}$ & 1.00 & & & \\
\hline & Sig. (2-tailed) & 0.000 & . & & & \\
\hline \multirow[t]{2}{*}{ Financial Wealth } & Correlation Coefficient & $0.98^{* *}$ & $0.95^{\star *}$ & 1.00 & & \\
\hline & Sig. (2-tailed) & 0.000 & 0.000 & . & & \\
\hline \multirow[t]{2}{*}{ Physical Wealth } & Correlation Coefficient & $0.94^{* *}$ & $0.95^{\star *}$ & $0.93^{\star *}$ & 1.00 & \\
\hline & Sig. (2-tailed) & 0.000 & 0.000 & 0.000 & . & \\
\hline \multirow[t]{2}{*}{ Total Wealth } & Correlation Coefficient & $0.98^{\star *}$ & $0.98^{\star *}$ & $0.98^{\star *}$ & $0.96^{\star *}$ & 1.00 \\
\hline & Sig. (2-tailed) & 0.000 & 0.000 & 0.000 & 0.000 & . \\
\hline
\end{tabular}

** Correlation is significant at the 0.01 level (2-tailed test) 
The relative rankings of the different wealth types for each supergroup are also revealing: for supergroups 3 and 7 , their property ranking tends to be higher than that for other wealth types, whereas this tends to be low for 1 and 5 , for whom physical wealth ranking is more to the fore. For supergroup 4, particularly groups a and b, pension wealth is important, as it is for some of the older subgroups, such as $1 \mathrm{c} 3$ and $5 \mathrm{~b} 4$.

\section{Conclusion}

The foregoing analysis provides an illustration of the use of Output Areas in providing a geographic representation of the distribution of wealth across 'zones of similarity' progressing from aggregate to relatively disaggregated levels, whilst simultaneously avoiding disclosivity.

Although there is a good deal of variation within the OAC groupings and the extreme skewness of the data needs to be borne in mind, the presentation of wealth statistics by classification into the supergroups, groups and subgroups by demographic, housing and socio-economic criteria does provide helpful insight.

Across the four wealth types and for total wealth supergroups 3 and 4, Countryside and Prospering Suburbs, consistently exhibited the highest mean and median wealth while supergroups 5 , 1 and 7 , Constrained by Circumstances, Blue Collar Communities and Multicultural, had the lowest levels of wealth. Disaggregation to group and subgroup levels generally presents a similar picture with a few notable exceptions. Thus groups and subgroups within supergroups 3 and 4 tended to have the highest means and medians and those within 5,1 and 7 the lowest. Those few groups and subgroups which do not follow the trend for lower wealth supergroups tend to be those with relatively older and better qualified households, while from the higher wealth supergroups, it is the younger and more transient households which tend to be the exceptions. The divergence between the high and low wealth OAC categories is considerable. Thus, the median total wealth for supergroup 4 is about nine times that of supergroup 5 , which is magnified at subgroup level - the median for subgroup $4 \mathrm{~b} 3$ is fifty times that of subgroup $5 \mathrm{c} 3$.

The consistency of ranking of supergroups for all wealth types follows through into the more disaggregated groupings: in general those with low wealth had low wealth for all types and vice versa, although, again there are a few exceptions. However, it is notable that different types of wealth appear to take precedence for different supergroups

As the introduction suggested, the geographical distribution of wealth is the outcome of a multiplicity of factors, although indicators for some of these are used in the determination of the OAC grouping. Further study could analyse the impact of these on the geography of wealth. The approach taken here could also be useful for both gauging the geodemographic effects of current policies as well as for the development of geographically focussed future policy initiatives.

Additionally, the WAS dataset is of such a richness, that much more study could be carried out on the different components of wealth and indebtedness, and as datasets from wave 2 and further 
waves become available, OAC analysis should further enhance our understanding of the geography of changes in wealth.

\section{Acknowledgements}

The authors are grateful for comments and advice from Keith Dugmore of the Demographic User Group, Nick Richardson and Deborah Rhodes of ONS Mapping Services, and the HAS Research Team. However, any errors or omissions are the sole responsibility of the authors.

\section{Notes}

1. With the exception of the Scotland north of the Caledonian Canal, the Scottish Islands and the Isles of Scilly.

2. Only half of the sample was asked about physical wealth.

3. Because physical wealth figures are based on a half sample, total wealth is also calculated on that basis. Nevertheless, comparison of the wealth distributions for the half and full sample suggests that the conclusions would not be markedly different.

4. For a variable to be far above average it must have a difference of more than 0.15 above the UK mean. For a variable to be far below average it must have a difference of more than 0.15 below the UK mean (see ONS, 2005 for details of cluster summaries).

5. Some figures quoted in this article are based on data deposited at the UK Data Archive after the publication of 'Wealth in Great Britain'. Any differences in figures quoted for mean and median wealth - as a component of wealth or total wealth - are explained by corrections made during quality assurance checks prior to the deposit of data at UKDA.

6. Households without this type of asset were excluded (zeros).

7. For a variable to be 'far above average' it must have a difference of more than 0.15 above the UK mean (see ONS, 2005 for details of cluster summaries)

\section{Contact}

elmr@ons.gov.uk

\section{References}

ONS (2005) 'Area Classification for output areas - cluster summaries' www.statistics.gov.uk/about/methodology_by_theme/area_classification/oa/cluster_summaries.asp

ONS (2009) 'Wealth in Great Britain. Main results from the Wealth and Assets Survey 2006/08'http://www.statistics.gov.uk/downloads/theme_economy/wealth-assets-20062008/Wealth_in_GB_2006_2008.pdf 
Vickers D, Rees P and Birkin M (2005) Creating the National Classification of Census Output Areas: Data, Methods and Results. Working Paper 05/2, School of Geography, University of Leeds www.geog.leeds.ac.uk/fileadmin/downloads/school/research/wpapers/05-2.pdf

Vickers, D and Rees, P (2006) Introducing the Area Classification of Output Areas Population Trends 125, ONS.

www.statistics.gov.uk/downloads/theme_population/PT125_main_part2.pdf

Williams, S and Botterill, A (2006) Profiling Areas using the Output Area Classification Regional Trends 39, ONS.

www.statistics.gov.uk/articles/RegionalTrends/Article2RT39.pdf 
Annex 1: Wealth total and components, 2006/08

\begin{tabular}{|c|c|c|c|c|c|c|c|c|c|c|c|c|}
\hline \multirow[b]{2}{*}{ Output Area Classification } & \multirow[b]{2}{*}{$\begin{array}{l}\text { Weighted } \\
\text { Households }\end{array}$} & \multicolumn{2}{|c|}{ Property Wealth } & \multicolumn{2}{|c|}{ Pension Wealth } & \multicolumn{2}{|c|}{ Financial Wealth } & \multirow[b]{2}{*}{$\begin{array}{c}\text { Weighted } \\
\text { Households } \\
*\end{array}$} & \multicolumn{2}{|c|}{ Total Wealth* } & \multicolumn{2}{|c|}{ Physical Wealth* } \\
\hline & & Mean & Median & Mean & Median & Mean & Median & & Mean & Median & Mean & Median \\
\hline 1 - Blue Collar Communities & $3,951,681$ & $£ 63,037$ & $£ 34,000$ & $£ 70,443$ & $£ 9,754$ & $£ 13,059$ & $£ 893$ & $2,181,845$ & $£ 180,437$ & $£ 104,400$ & $£ 32,056$ & $£ 25,500$ \\
\hline 1a - Terraced blue collar & 924,083 & $£ 45,472$ & $£ 0$ & $£ 59,756$ & $£ 7,500$ & $£ 8,427$ & $£ 411$ & 515,651 & $£ 141,175$ & $£ 70,750$ & $£ 30,492$ & $£ 25,000$ \\
\hline 1a1 & 362,111 & $£ 32,729$ & $£ 0$ & $£ 49,405$ & $£ 2,000$ & $£ 4,006$ & $£ 100$ & 193,907 & $£ 113,209$ & $£ 58,964$ & $£ 25,943$ & $£ 21,300$ \\
\hline $1 \mathrm{a} 2$ & 255,341 & $£ 63,175$ & $£ 60,000$ & $£ 77,282$ & $£ 20,000$ & $£ 12,197$ & $£ 1,400$ & 140,211 & $£ 194,662$ & $£ 131,754$ & $£ 33,159$ & $£ 28,000$ \\
\hline 1a3 & 306630 & $£ 45,779$ & $£ 0$ & $£ 57,385$ & $£ 7,436$ & $£ 10,507$ & $£ 388$ & 181,532 & $£ 129,734$ & $£ 55,553$ & $£ 33,290$ & $£ 25,000$ \\
\hline 1b - Younger blue collar & 1597426 & $£ 49,861$ & $£ 11,700$ & $£ 50,745$ & $£ 3,807$ & $£ 7,681$ & $£ 400$ & 884,508 & $£ 139,975$ & $£ 73,737$ & $£ 30,034$ & $£ 25,000$ \\
\hline 1b1 & 934,339 & $£ 49,247$ & $£ 0$ & $£ 48,701$ & $£ 2,770$ & $£ 7,486$ & $£ 290$ & 511,662 & $£ 139,229$ & $£ 64,134$ & $£ 30,267$ & $£ 25,000$ \\
\hline $1 \mathrm{~b} 2$ & 663,087 & $£ 50,725$ & $£ 26,000$ & $£ 53,626$ & $£ 6,265$ & $£ 7,957$ & $£ 585$ & 372,847 & $£ 140,999$ & $£ 84,468$ & $£ 29,715$ & $£ 25,000$ \\
\hline 1c - Older blue collar & $1,430,172$ & $£ 89,104$ & $£ 74,000$ & $£ 99,350$ & $£ 22,186$ & $£ 22,059$ & $£ 3,000$ & 781,686 & $£ 252,122$ & $£ 167,882$ & $£ 35,377$ & $£ 28,750$ \\
\hline $1 \mathrm{c} 1$ & 582016 & $£ 91,255$ & $£ 72,000$ & $£ 101,152$ & $£ 19,329$ & $£ 26,997$ & $£ 2,500$ & 327,567 & $£ 275,350$ & $£ 176,085$ & $£ 36,586$ & $£ 30,000$ \\
\hline 1c2 & 285913 & $£ 76,640$ & $£ 62,000$ & $£ 83,099$ & $£ 20,035$ & $£ 11,796$ & $£ 2,000$ & 163,525 & $£ 209,196$ & $£ 123,220$ & $£ 32,874$ & $£ 27,000$ \\
\hline $1 \mathrm{c} 3$ & 562243 & $£ 93,215$ & $£ 84,000$ & $£ 105,748$ & $£ 26,246$ & $£ 22,166$ & $£ 3,850$ & 290,594 & $£ 250,094$ & $£ 182,396$ & $£ 35,423$ & $£ 29,000$ \\
\hline 2 - City Living & 1585629 & $£ 169,420$ & $£ 51,000$ & $£ 144,620$ & $£ 15,250$ & $£ 48,561$ & $£ 6,045$ & 893,490 & $£ 388,722$ & $£ 146,375$ & $£ 36,015$ & $£ 25,000$ \\
\hline 2a-Transient communities & 586,599 & $£ 130,418$ & $£ 5,000$ & $£ 101,705$ & $£ 5,468$ & $£ 38,199$ & $£ 3,600$ & 321,316 & $£ 296,666$ & $£ 88,335$ & $£ 30,306$ & $£ 17,000$ \\
\hline $2 \mathrm{a} 1$ & 254,648 & $£ 89,588$ & $£ 7,000$ & $£ 72,381$ & $£ 5,000$ & $£ 18,534$ & $£ 2,350$ & 130,500 & $£ 242,800$ & $£ 71,750$ & $£ 23,131$ & $£ 15,000$ \\
\hline $2 \mathrm{a} 2$ & 331,951 & $£ 161,740$ & $£ 0$ & $£ 124,200$ & $£ 6,500$ & $£ 53,284$ & $£ 7,000$ & 190,816 & $£ 333,504$ & $£ 104,696$ & $£ 35,213$ & $£ 23,000$ \\
\hline $2 \mathrm{~b}$ - Settled in the city & 999,030 & $£ 192,321$ & $£ 85,000$ & $£ 169,819$ & $£ 22,000$ & $£ 54,645$ & $£ 7,958$ & 572,174 & $£ 440,419$ & $£ 213,000$ & $£ 39,220$ & $£ 25,500$ \\
\hline $2 \mathrm{~b} 1$ & 377,315 & $£ 146,580$ & $£ 81,000$ & $£ 151,744$ & $£ 26,596$ & $£ 46,897$ & $£ 5,300$ & 224,628 & $£ 395,741$ & $£ 169,690$ & $£ 35,470$ & $£ 25,000$ \\
\hline $2 \mathrm{~b} 2$ & 621,715 & $£ 220,081$ & $£ 90,000$ & $£ 180,788$ & $£ 20,456$ & $£ 59,348$ & $£ 9,400$ & 347,546 & $£ 469,295$ & $£ 237,667$ & $£ 41,644$ & $£ 26,000$ \\
\hline 3 - Countryside & $2,828,953$ & $£ 258,182$ & $£ 188,000$ & $£ 224,241$ & $£ 68,361$ & $£ 75,845$ & $£ 18,750$ & $1,616,912$ & $£ 622,271$ & $£ 386,242$ & $£ 56,861$ & $£ 44,700$ \\
\hline 3a - Village life & $1,198,879$ & $£ 202,313$ & $£ 154,768$ & $£ 188,598$ & $£ 59,208$ & $£ 62,155$ & $£ 13,400$ & 697,775 & $£ 484,549$ & $£ 324,455$ & $£ 49,027$ & $£ 39,000$ \\
\hline $3 a 1$ & 610,710 & $£ 183,161$ & $£ 150,000$ & $£ 197,090$ & $£ 68,000$ & $£ 56,995$ & $£ 13,000$ & 353,506 & $£ 457,407$ & $£ 320,300$ & $£ 47,226$ & $£ 39,000$ \\
\hline $3 \mathrm{a} 2$ & 588,169 & $£ 222,198$ & $£ 160,000$ & $£ 179,780$ & $£ 52,632$ & $£ 67,513$ & $£ 13,800$ & 344,269 & $£ 512,419$ & $£ 327,550$ & $£ 50,877$ & $£ 38,500$ \\
\hline $3 b-$ Agricultural & 659,511 & $£ 304,151$ & $£ 200,000$ & $£ 233,845$ & $£ 60,351$ & $£ 83,796$ & $£ 23,002$ & 372,168 & $£ 694,364$ & $£ 411,764$ & $£ 63,133$ & $£ 47,300$ \\
\hline $3 \mathrm{~b} 1$ & 335,966 & $£ 302,213$ & $£ 220,000$ & $£ 271,783$ & $£ 69,712$ & $£ 81,992$ & $£ 24,499$ & 188,701 & $£ 693,651$ & $£ 406,887$ & $£ 67,965$ & $£ 49,500$ \\
\hline $3 \mathrm{~b} 2$ & 323,546 & $£ 306,163$ & $£ 200,000$ & $£ 194,451$ & $£ 49,639$ & $£ 85,668$ & $£ 22,700$ & 183,468 & $£ 695,098$ & $£ 422,742$ & $£ 58,163$ & $£ 43,000$ \\
\hline 3c - Accessible countryside & 970,563 & $£ 295,958$ & $£ 202,000$ & $£ 261,744$ & $£ 85,000$ & $£ 87,353$ & $£ 26,000$ & 546,969 & $£ 748,910$ & $£ 485,951$ & $£ 62,587$ & $£ 47,500$ \\
\hline $3 c 1$ & 556,398 & $£ 276,186$ & $£ 200,868$ & $£ 283,170$ & $£ 92,118$ & $£ 81,098$ & $£ 26,445$ & 314,829 & $£ 735,341$ & $£ 492,170$ & $£ 58,362$ & $£ 47,800$ \\
\hline $3 \mathrm{c} 2$ & 414,165 & $£ 322,520$ & $£ 208,000$ & $£ 232,959$ & $£ 73,931$ & $£ 95,755$ & $£ 22,851$ & 232,140 & $£ 767,312$ & $£ 470,971$ & $£ 68,319$ & $£ 47,500$ \\
\hline 4 - Prospering suburbs & $5,287,073$ & $£ 223,443$ & $£ 180,000$ & $£ 237,058$ & $£ 103,772$ & $£ 67,466$ & $£ 24,200$ & $2,957,792$ & $£ 596,748$ & $£ 420,839$ & $£ 53,145$ & $£ 44,500$ \\
\hline 4a - Prospering younger families & $1,020,743$ & $£ 185,331$ & $£ 156,870$ & $£ 226,455$ & $£ 101,829$ & $£ 51,553$ & $£ 18,460$ & 576,267 & $£ 529,607$ & $£ 389,883$ & $£ 49,874$ & $£ 42,250$ \\
\hline 4a1 & 366,865 & $£ 174,527$ & $£ 150,000$ & $£ 259,998$ & $£ 151,176$ & $£ 47,494$ & $£ 17,000$ & 207,799 & $£ 589,706$ & $£ 450,290$ & $£ 51,896$ & $£ 44,300$ \\
\hline $4 \mathrm{a} 2$ & 653,879 & $£ 191,393$ & $£ 160,000$ & $£ 207,635$ & $£ 90,670$ & $£ 53,830$ & $£ 19,260$ & 368,468 & $£ 495,715$ & $£ 339,904$ & $£ 48,734$ & $£ 41,000$ \\
\hline $4 \mathrm{~b}$ - Prospering older families & $1,586,949$ & $£ 270,835$ & $£ 222,000$ & $£ 284,668$ & $£ 137,169$ & $£ 85,644$ & $£ 37,548$ & 916,105 & $£ 713,978$ & $£ 507,636$ & $£ 58,084$ & $£ 49,000$ \\
\hline $4 \mathrm{~b} 1$ & 444,737 & $£ 222,102$ & $£ 200,000$ & $£ 200,021$ & $£ 97,541$ & $£ 66,452$ & $£ 27,367$ & 263,623 & $£ 529,337$ & $£ 417,515$ & $£ 49,734$ & $£ 46,000$ \\
\hline $4 \mathrm{~b} 2$ & 427,299 & $£ 208,496$ & $£ 190,000$ & $£ 286,133$ & $£ 129,991$ & $£ 58,989$ & $£ 29,535$ & 238,044 & $£ 564,348$ & $£ 428,332$ & $£ 51,726$ & $£ 48,000$ \\
\hline $4 \mathrm{~b} 3$ & 335,729 & $£ 401,610$ & $£ 307,000$ & $£ 359,356$ & $£ 200,671$ & $£ 136,336$ & $£ 64,370$ & 193,629 & $£ 1,045,497$ & $£ 788,875$ & $£ 74,067$ & $£ 55,500$ \\
\hline $4 \mathrm{~b} 4$ & 379,183 & $£ 282,455$ & $£ 235,000$ & $£ 316,171$ & $£ 153,451$ & $£ 93,308$ & $£ 43,320$ & 220,809 & $£ 805,020$ & $£ 562,920$ & $£ 60,893$ & $£ 48,000$ \\
\hline 4c - Prospering semis & $1,561,917$ & $£ 160,445$ & $£ 150,000$ & $£ 170,307$ & $£ 78,369$ & $£ 41,216$ & $£ 14,650$ & 841,987 & $£ 414,573$ & $£ 318,407$ & $£ 46,301$ & $£ 38,000$ \\
\hline
\end{tabular}




\begin{tabular}{|c|c|c|c|c|c|c|c|c|c|c|c|c|}
\hline $4 \mathrm{c} 1$ & 512,280 & $£ 140,454$ & $£ 140,000$ & $£ 143,382$ & $£ 70,027$ & $£ 36,411$ & $£ 10,500$ & 269,605 & $£ 361,313$ & $£ 284,780$ & $£ 42,432$ & $£ 38,000$ \\
\hline $4 \mathrm{c} 2$ & 680,490 & $£ 173,238$ & $£ 162,000$ & $£ 180,243$ & $£ 82,569$ & $£ 45,922$ & $£ 16,000$ & 348,316 & $£ 446,274$ & $£ 329,183$ & $£ 48,596$ & $£ 37,000$ \\
\hline $4 c 3$ & 369,147 & $£ 164,605$ & $£ 150,000$ & $£ 189,356$ & $£ 86,890$ & $£ 39,211$ & $£ 18,300$ & 224,066 & $£ 429,377$ & $£ 340,779$ & $£ 47,389$ & $£ 41,000$ \\
\hline $4 d$ - Thriving suburbs & $1,117,464$ & $£ 279,009$ & $£ 220,000$ & $£ 272,430$ & $£ 105,518$ & $£ 92,879$ & $£ 31,400$ & 623,433 & $£ 732,586$ & $£ 512,500$ & $£ 58,153$ & $£ 47,000$ \\
\hline $4 \mathrm{~d} 1$ & 375,657 & $£ 341,626$ & $£ 280,000$ & $£ 268,247$ & $£ 97,042$ & $£ 110,136$ & $£ 32,820$ & 202,613 & $£ 834,227$ & $£ 561,831$ & $£ 63,321$ & $£ 50,700$ \\
\hline $4 \mathrm{~d} 2$ & 741,807 & $£ 247,300$ & $£ 200,000$ & $£ 274,548$ & $£ 116,214$ & $£ 84,140$ & $£ 30,950$ & 420,820 & $£ 683,649$ & $£ 477,458$ & $£ 55,664$ & $£ 45,000$ \\
\hline 5 - Constrained by circumstances & $3,094,081$ & $£ 43,806$ & $£ 0$ & $£ 60,128$ & $£ 2,000$ & $£ 10,454$ & $£ 500$ & $1,766,079$ & $£ 135,526$ & $£ 44,379$ & $£ 25,124$ & $£ 15,500$ \\
\hline 5a - Senior Communities & 426,303 & $£ 29,524$ & $£ 0$ & $£ 54,676$ & $£ 1,437$ & $£ 7,750$ & $£ 677$ & 241,873 & $£ 110,469$ & $£ 34,830$ & $£ 19,747$ & $£ 15,000$ \\
\hline $5 a 1$ & 270,767 & $£ 15,972$ & $£ 0$ & $£ 39,660$ & $£ 0$ & $£ 3,258$ & $£ 247$ & 156,413 & $£ 68,755$ & $£ 25,624$ & $£ 18,710$ & $£ 15,000$ \\
\hline $5 \mathrm{a} 2$ & 155,536 & $£ 53,117$ & $£ 0$ & $£ 80,817$ & $£ 10,023$ & $£ 15,571$ & $£ 2,500$ & 85,460 & $£ 186,817$ & $£ 55,127$ & $£ 21,645$ & $£ 15,000$ \\
\hline $5 b$ - Older Workers & $1,956,523$ & $£ 55,556$ & $£ 0$ & $£ 73,516$ & $£ 5,059$ & $£ 13,449$ & $£ 880$ & $1,118,678$ & $£ 165,238$ & $£ 71,730$ & $£ 28,272$ & $£ 18,000$ \\
\hline $5 b 1$ & 372,503 & $£ 46,912$ & $£ 0$ & $£ 68,349$ & $£ 14,522$ & $£ 12,747$ & $£ 1,291$ & 213,611 & $£ 150,152$ & $£ 79,642$ & $£ 28,150$ & $£ 18,800$ \\
\hline $5 b 2$ & 444,939 & $£ 90,092$ & $£ 40,000$ & $£ 84,688$ & $£ 12,000$ & $£ 25,401$ & $£ 2,549$ & 258,406 & $£ 254,495$ & $£ 143,194$ & $£ 38,128$ & $£ 25,000$ \\
\hline $5 b 3$ & 677,576 & $£ 46,083$ & $£ 0$ & $£ 52,352$ & $£ 2,290$ & $£ 7,575$ & $£ 450$ & 377,323 & $£ 132,226$ & $£ 52,210$ & $£ 25,224$ & $£ 16,500$ \\
\hline $5 b 4$ & 461,505 & $£ 43,142$ & $£ 0$ & $£ 97,987$ & $£ 1,803$ & $£ 11,115$ & $£ 465$ & 269,339 & $£ 137,816$ & $£ 49,456$ & $£ 23,184$ & $£ 15,000$ \\
\hline 5c - Public Housing & 711,256 & $£ 20,043$ & $£ 0$ & $£ 26,568$ & $£ 0$ & $£ 3,839$ & $£ 40$ & 405,528 & $£ 68,509$ & $£ 20,595$ & $£ 19,648$ & $£ 15,000$ \\
\hline $5 c 1$ & 245,628 & $£ 22,796$ & $£ 0$ & $£ 36,409$ & $£ 0$ & $£ 5,359$ & $£ 110$ & 140,450 & $£ 84,390$ & $£ 27,754$ & $£ 21,354$ & $£ 15,000$ \\
\hline $5 c 2$ & 161,596 & $£ 24,333$ & $£ 0$ & $£ 29,130$ & $£ 0$ & $£ 5,064$ & $£ 100$ & 88,963 & $£ 83,441$ & $£ 19,510$ & $£ 18,277$ & $£ 15,000$ \\
\hline $5 c 3$ & 304,032 & $£ 15,540$ & $£ 0$ & $£ 17,257$ & $£ 0$ & $£ 1,960$ & $£ 0$ & 176,115 & $£ 48,300$ & $£ 15,801$ & $£ 18,980$ & $£ 10,500$ \\
\hline 6 - Typical traits & $5,134,247$ & $£ 136,594$ & $£ 106,400$ & $£ 139,852$ & $£ 41,443$ & $£ 34,976$ & $£ 6,900$ & $2,911,111$ & $£ 349,400$ & $£ 223,770$ & $£ 39,037$ & $£ 31,900$ \\
\hline $6 a-$ Settled households & $1,431,177$ & $£ 125,671$ & $£ 111,000$ & $£ 129,041$ & $£ 50,392$ & $£ 30,083$ & $£ 7,576$ & 801,901 & $£ 328,319$ & $£ 238,129$ & $£ 40,710$ & $£ 35,000$ \\
\hline $6 a 1$ & 889,857 & $£ 119,897$ & $£ 106,000$ & $£ 129,151$ & $£ 48,375$ & $£ 30,532$ & $£ 7,800$ & 513,434 & $£ 314,407$ & $£ 234,907$ & $£ 40,874$ & $£ 35,300$ \\
\hline $6 \mathrm{a} 2$ & 541,320 & $£ 135,162$ & $£ 120,000$ & $£ 128,860$ & $£ 53,063$ & $£ 29,345$ & $£ 7,422$ & 288,467 & $£ 353,080$ & $£ 251,970$ & $£ 40,418$ & $£ 35,000$ \\
\hline $6 \mathrm{~b}$ - Least divergent & $1,406,729$ & $£ 140,662$ & $£ 112,000$ & $£ 145,467$ & $£ 41,134$ & $£ 38,620$ & $£ 8,300$ & 809,758 & $£ 359,402$ & $£ 245,600$ & $£ 40,635$ & $£ 33,500$ \\
\hline $6 \mathrm{~b} 1$ & 384,042 & $£ 141,366$ & $£ 100,000$ & $£ 146,896$ & $£ 25,460$ & $£ 45,219$ & $£ 7,580$ & 215,401 & $£ 348,927$ & $£ 215,610$ & $£ 40,318$ & $£ 27,700$ \\
\hline $6 \mathrm{~b} 2$ & 520,980 & $£ 149,174$ & $£ 115,000$ & $£ 158,488$ & $£ 49,000$ & $£ 40,060$ & $£ 9,501$ & 311,432 & $£ 388,459$ & $£ 254,847$ & $£ 41,486$ & $£ 35,000$ \\
\hline $6 b 3$ & 501,707 & $£ 131,283$ & $£ 120,000$ & $£ 130,851$ & $£ 41,134$ & $£ 32,072$ & $£ 7,292$ & 282,925 & $£ 335,391$ & $£ 240,288$ & $£ 39,938$ & $£ 33,000$ \\
\hline $\begin{array}{l}6 c-\text { Young families in terraced } \\
\text { homes }\end{array}$ & $1,231,481$ & $£ 86,344$ & $£ 70,000$ & $£ 91,395$ & $£ 17,650$ & $£ 16,395$ & $£ 2,000$ & 719,955 & $£ 223,465$ & $£ 147,927$ & $£ 29,516$ & $£ 25,000$ \\
\hline $6 c 1$ & 590,784 & $£ 89,429$ & $£ 76,500$ & $£ 99,053$ & $£ 19,686$ & $£ 16,122$ & $£ 2,020$ & 331,477 & $£ 236,639$ & $£ 156,587$ & $£ 30,427$ & $£ 25,000$ \\
\hline $6 c 2$ & 640,698 & $£ 83,499$ & $£ 57,000$ & $£ 84,334$ & $£ 15,847$ & $£ 16,647$ & $£ 1,970$ & 388,478 & $£ 212,224$ & $£ 136,248$ & $£ 28,739$ & $£ 25,000$ \\
\hline $6 d$ - Aspiring households & $1,064,860$ & $£ 204,014$ & $£ 159,434$ & $£ 203,004$ & $£ 69,050$ & $£ 58,226$ & $£ 16,000$ & 579,497 & $£ 521,055$ & $£ 352,975$ & $£ 46,317$ & $£ 37,000$ \\
\hline $6 \mathrm{~d} 1$ & 541,000 & $£ 196,392$ & $£ 150,000$ & $£ 200,782$ & $£ 69,314$ & $£ 55,302$ & $£ 14,200$ & 288,369 & $£ 503,389$ & $£ 335,356$ & $£ 44,634$ & $£ 35,500$ \\
\hline $6 \mathrm{~d} 2$ & 523,860 & $£ 211,885$ & $£ 165,000$ & $£ 205,300$ & $£ 67,695$ & $£ 61,246$ & $£ 18,500$ & 291,128 & $£ 538,553$ & $£ 365,568$ & $£ 47,984$ & $£ 38,800$ \\
\hline 7 - Multicultural & $2,702,036$ & $£ 94,155$ & $£ 0$ & $£ 69,841$ & $£ 400$ & $£ 21,313$ & $£ 750$ & $1,574,053$ & $£ 212,694$ & $£ 71,513$ & $£ 26,772$ & $£ 16,300$ \\
\hline $7 a-$ Asian communities & $1,565,070$ & $£ 108,294$ & $£ 45,000$ & $£ 76,357$ & $£ 4,050$ & $£ 22,051$ & $£ 1,100$ & 902,948 & $£ 243,707$ & $£ 111,799$ & $£ 29,627$ & $£ 20,000$ \\
\hline $7 a 1$ & 379,082 & $£ 60,776$ & $£ 6,000$ & $£ 27,429$ & $£ 0$ & $£ 6,881$ & $£ 440$ & 215,278 & $£ 121,273$ & $£ 66,400$ & $£ 23,128$ & $£ 15,000$ \\
\hline $7 \mathrm{a} 2$ & 506,258 & $£ 71,231$ & $£ 3,000$ & $£ 69,508$ & $£ 5,000$ & $£ 14,185$ & $£ 520$ & 300,445 & $£ 185,387$ & $£ 82,050$ & $£ 25,979$ & $£ 19,000$ \\
\hline $7 a 3$ & 679,729 & $£ 162,398$ & $£ 102,000$ & $£ 108,744$ & $£ 18,000$ & $£ 36,369$ & $£ 4,050$ & 387,225 & $£ 357,025$ & $£ 228,769$ & $£ 36,070$ & $£ 25,000$ \\
\hline $7 \mathrm{~b}$ - Afro-Caribbean communities & $1,136,966$ & $£ 74,693$ & $£ 0$ & $£ 60,872$ & $£ 0$ & $£ 20,296$ & $£ 400$ & 671,105 & $£ 170,967$ & $£ 33,000$ & $£ 22,931$ & $£ 15,000$ \\
\hline $7 \mathrm{~b} 1$ & 681,931 & $£ 102,183$ & $£ 0$ & $£ 80,236$ & $£ 1,264$ & $£ 29,736$ & $£ 1,100$ & 410,726 & $£ 224,731$ & $£ 61,660$ & $£ 25,885$ & $£ 15,000$ \\
\hline $7 \mathrm{~b} 2$ & 455,035 & $£ 33,495$ & $£ 0$ & $£ 31,851$ & $£ 0$ & $£ 6,150$ & $£ 50$ & 260,378 & $£ 86,159$ & $£ 17,186$ & $£ 18,271$ & $£ 12,500$ \\
\hline Great Britain & $24,583,701$ & $£ 143,214$ & $£ 95,000$ & $£ 141,890$ & $£ 29,145$ & $£ 39,432$ & $£ 5,140$ & $13,901,282$ & $£ 367,125$ & $£ 204,607$ & $£ 39,666$ & $£ 29,900$ \\
\hline
\end{tabular}

Source: Wealth and Assets survey

* Refers to half the sample only 


\section{Annex 2: Standard errors for mean values}

\begin{tabular}{|c|c|c|c|c|c|c|c|}
\hline & & $\begin{array}{l}\text { Property } \\
\text { Wealth }\end{array}$ & Pension Wealth & Financial Wealth & & $\begin{array}{l}\text { Physical } \\
\text { Wealth*}^{*}\end{array}$ & Total Wealth* \\
\hline Output Area Classification & $\begin{array}{l}\text { Weighted } \\
\text { Households }\end{array}$ & S.E & S.E & S.E & $\begin{array}{l}\text { Weighted } \\
\text { Households* }\end{array}$ & S.E & S.E \\
\hline 1 - Blue Collar Communities & $3,951,681$ & 1,297 & 2,625 & 712 & $2,181,845$ & 625 & 5,318 \\
\hline 1a - Terraced blue collar & 924,083 & 1,989 & 3,813 & 1,036 & 515,651 & 1,170 & 7,231 \\
\hline $1 \mathrm{a} 1$ & 362,111 & 2,865 & 5,535 & 823 & 193,907 & 1,406 & 10,276 \\
\hline $1 \mathrm{a} 2$ & 255,341 & 3,601 & 7,741 & 1,638 & 140,211 & 2,305 & 16,449 \\
\hline 1a3 & 306,630 & 3,725 & 6,938 & 2,615 & 181,532 & 2,356 & 11,395 \\
\hline 1b - Younger blue collar & $1,597,426$ & 1,902 & 3,159 & 742 & 884,508 & 1,096 & 6,573 \\
\hline $1 \mathrm{~b} 1$ & 934,339 & 2,692 & 4,019 & 1,018 & 511,662 & 1,618 & 8,916 \\
\hline $1 \mathrm{~b} 2$ & 663,087 & 2,557 & 5,085 & 1,060 & 372,847 & 1,351 & 9,638 \\
\hline 1c - Older blue collar & $1,430,172$ & 2,470 & 5,800 & 1,633 & 781,686 & 953 & 11,614 \\
\hline $1 \mathrm{c} 1$ & 582,016 & 4,303 & 10,776 & 3,114 & 327,567 & 1,400 & 21,793 \\
\hline $1 \mathrm{c} 2$ & 285,913 & 4,627 & 10,585 & 1,526 & 163,525 & 2,402 & 20,800 \\
\hline $1 \mathrm{c} 3$ & 562,243 & 3,728 & 7,984 & 2,478 & 290,594 & 1,498 & 15,215 \\
\hline 2 - City Living & $1,585,629$ & 9,350 & 13,308 & 3,389 & 893,490 & 1,621 & 22,930 \\
\hline 2a - Transient communities & 586,599 & 17,145 & 17,065 & 5,814 & 321,316 & 2,553 & 32,577 \\
\hline $2 \mathrm{a} 1$ & 254,648 & 24,137 & 12,111 & 3,508 & 130,500 & 3,561 & 56,434 \\
\hline $2 \mathrm{a} 2$ & 331,951 & 23,768 & 28,697 & 9,876 & 190,816 & 3,502 & 38,804 \\
\hline $2 \mathrm{~b}-$ Settled in the city & 999,030 & 10,675 & 18,569 & 4,120 & 572,174 & 2,074 & 30,382 \\
\hline $2 \mathrm{~b} 1$ & 377,315 & 10,806 & 15,247 & 5,450 & 224,628 & 2,760 & 37,430 \\
\hline $2 \mathrm{~b} 2$ & 621,715 & 15,722 & 28,376 & 5,717 & 347,546 & 2,905 & 43,584 \\
\hline 3 - Countryside & $2,828,953$ & 5,971 & 10,948 & 2,656 & $1,616,912$ & 1,378 & 20,005 \\
\hline 3a - Village life & $1,198,879$ & 6,626 & 16,009 & 3,768 & 697,775 & 1,660 & 19,145 \\
\hline $3 a 1$ & 610,710 & 6,877 & 28,754 & 5,333 & 353,506 & 1,804 & 23,815 \\
\hline $3 \mathrm{a} 2$ & 588,169 & 11,512 & 13,194 & 5,312 & 344,269 & 2,817 & 30,303 \\
\hline $3 b-$ Agricultural & 659,511 & 14,271 & 23,197 & 5,251 & 372,168 & 3,489 & 48,276 \\
\hline $3 b 1$ & 335,966 & 15,421 & 42,288 & 7,506 & 188,701 & 5,886 & 81,303 \\
\hline $3 \mathrm{~b} 2$ & 323,546 & 24,242 & 17,406 & 7,310 & 183,468 & 3,565 & 50,782 \\
\hline 3c - Accessible countryside & 970,563 & 11,763 & 19,403 & 5,011 & 546,969 & 2,496 & 42,269 \\
\hline $3 c 1$ & 556,398 & 11,782 & 30,832 & 5,817 & 314,829 & 2,920 & 58,266 \\
\hline $3 c 2$ & 414,165 & 22,362 & 18,704 & 8,308 & 232,140 & 4,323 & 60,652 \\
\hline 4 - Prospering suburbs & $5,287,073$ & 2,901 & 5,260 & 1,674 & $2,957,792$ & 718 & 11,090 \\
\hline 4a - Prospering younger families & $1,020,743$ & 6,303 & 13,026 & 3,001 & 576,267 & 1,378 & 24,955 \\
\hline $4 \mathrm{a} 1$ & 366,865 & 8,510 & 27,222 & 5,207 & 207,799 & 2,526 & 51,488 \\
\hline $4 \mathrm{a} 2$ & 653,879 & 8,606 & 13,437 & 3,681 & 368,468 & 1,616 & 25,938 \\
\hline $4 \mathrm{~b}$ - Prospering older families & $1,586,949$ & 6,498 & 10,540 & 3,345 & 916,105 & 1,376 & 21,660 \\
\hline $4 \mathrm{~b} 1$ & 444,737 & 5,460 & 13,462 & 4,391 & 263,623 & 1,751 & 20,866 \\
\hline $4 \mathrm{~b} 2$ & 427,299 & 7,500 & 21,951 & 4,521 & 238,044 & 2,125 & 30,669 \\
\hline $4 \mathrm{~b} 3$ & 335,729 & 23,667 & 22,244 & 11,274 & 193,629 & 4,290 & 67,292 \\
\hline $4 \mathrm{~b} 4$ & 379,183 & 12,072 & 25,941 & 6,223 & 220,809 & 2,756 & 48,994 \\
\hline $4 \mathrm{c}-$ Prospering semis & $1,561,917$ & 2,688 & 6,168 & 1,809 & 841,987 & 1,250 & 11,348 \\
\hline
\end{tabular}




\begin{tabular}{|c|c|c|c|c|c|c|c|}
\hline $4 \mathrm{c} 1$ & 512,280 & 4,398 & 10,111 & 3,150 & 269,605 & 1,718 & 17,755 \\
\hline $4 \mathrm{c} 2$ & 680,490 & 4,121 & 9,294 & 2,989 & 348,316 & 2,306 & 19,013 \\
\hline $4 c 3$ & 369,147 & 5,741 & 13,624 & 3,099 & 224,066 & 2,221 & 22,237 \\
\hline $4 \mathrm{~d}-$ Thriving suburbs & $1,117,464$ & 6,847 & 13,348 & 5,027 & 623,433 & 1,705 & 30,088 \\
\hline $4 \mathrm{~d} 1$ & 375,657 & 14,126 & 20,573 & 10,879 & 202,613 & 3,295 & 52,246 \\
\hline $4 \mathrm{~d} 2$ & 741,807 & 7,295 & 17,259 & 5,206 & 420,820 & 1,953 & 36,789 \\
\hline 5 - Constrained by circumstances & $3,094,081$ & 1,543 & 6,705 & 744 & $1,766,079$ & 1,163 & 6,117 \\
\hline 5a - Senior Communities & 426,303 & 3,098 & 11,834 & 1,374 & 241,873 & 1,038 & 19,299 \\
\hline $5 a 1$ & 270,767 & 2,054 & 10,363 & 1,532 & 156,413 & 1,207 & 7,372 \\
\hline $5 \mathrm{a} 2$ & 155,536 & 7,360 & 26,882 & 2,562 & 85,460 & 1,918 & 52,060 \\
\hline $5 b$ - Older Workers & $1,956,523$ & 2,106 & 10,230 & 1,095 & $1,118,678$ & 1,778 & 8,137 \\
\hline $5 b 1$ & 372,503 & 3,396 & 7,223 & 2,500 & 213,611 & 1,997 & 16,772 \\
\hline $5 b 2$ & 444,939 & 5,965 & 8,803 & 3,393 & 258,406 & 7,118 & 21,107 \\
\hline $5 b 3$ & 677,576 & 3,571 & 5,182 & 1,200 & 377,323 & 1,285 & 11,086 \\
\hline $5 b 4$ & 461,505 & 3,053 & 41,417 & 1,840 & 269,339 & 1,293 & 16,868 \\
\hline $5 c$ - Public Housing & 711,256 & 2,593 & 2,616 & 804 & 405,528 & 1,023 & 7,637 \\
\hline $5 c 1$ & 245,628 & 3,332 & 5,676 & 1,533 & 140,450 & 1,485 & 12,209 \\
\hline $5 c 2$ & 161,596 & 9,584 & 5,406 & 1,763 & 88,963 & 2,051 & 26,284 \\
\hline $5 c 3$ & 304,032 & 1,821 & 2,721 & 885 & 176,115 & 1,747 & 5,378 \\
\hline 6 - Typical traits & $5,134,247$ & 2,195 & 4,199 & 1,086 & $2,911,111$ & 628 & 7,957 \\
\hline $6 a-$ Settled households & $1,431,177$ & 2,674 & 5,183 & 1,748 & 801,901 & 1,089 & 10,153 \\
\hline $6 \mathrm{a} 1$ & 889,857 & 3,209 & 6,623 & 2,151 & 513,434 & 1,226 & 11,767 \\
\hline $6 \mathrm{a} 2$ & 541,320 & 4,660 & 8,319 & 2,977 & 288,467 & 2,098 & 18,837 \\
\hline $6 \mathrm{~b}-$ Least divergent & $1,406,729$ & 4,072 & 8,972 & 2,093 & 809,758 & 1,353 & 14,049 \\
\hline $6 \mathrm{~b} 1$ & 384,042 & 9,538 & 25,188 & 5,292 & 215,401 & 3,211 & 29,053 \\
\hline $6 \mathrm{~b} 2$ & 520,980 & 6,862 & 12,353 & 2,879 & 311,432 & 1,805 & 24,341 \\
\hline $6 b 3$ & 501,707 & 5,152 & 9,751 & 3,017 & 282,925 & 2,248 & 20,222 \\
\hline $\begin{array}{l}6 c \text { - Young families in terraced } \\
\text { homes }\end{array}$ & $1,231,481$ & 2,867 & 8,458 & 1,529 & 719,955 & 1,004 & 15,423 \\
\hline $6 \mathrm{c} 1$ & 590,784 & 3,857 & 15,139 & 2,581 & 331,477 & 1,735 & 27,975 \\
\hline $6 \mathrm{c} 2$ & 640,698 & 4,211 & 8,303 & 1,729 & 388,478 & 1,133 & 15,685 \\
\hline $6 \mathrm{~d}$ - Aspiring households & $1,064,860$ & 7,310 & 10,931 & 3,256 & 579,497 & 1,510 & 24,228 \\
\hline $6 \mathrm{~d} 1$ & 541,000 & 9,736 & 15,118 & 4,122 & 288,369 & 2,173 & 30,887 \\
\hline $6 \mathrm{~d} 2$ & 523,860 & 10,960 & 15,804 & 5,062 & 291,128 & 2,102 & 37,262 \\
\hline 7 - Multicultural & $2,702,036$ & 3,592 & 4,760 & 1,643 & $1,574,053$ & 888 & 10,185 \\
\hline $7 a-$ Asian communities & $1,565,070$ & 4,253 & 6,921 & 1,761 & 902,948 & 1,144 & 14,383 \\
\hline $7 a 1$ & 379,082 & 4,910 & 3,772 & 1,712 & 215,278 & 2,077 & 10,647 \\
\hline $7 \mathrm{a} 2$ & 506,258 & 5,190 & 16,365 & 2,346 & 300,445 & 1,307 & 30,737 \\
\hline $7 \mathrm{a} 3$ & 679,729 & 8,212 & 9,885 & 3,471 & 387,225 & 2,133 & 21,762 \\
\hline $7 \mathrm{~b}$ - Afro-Caribbean communities & $1,136,966$ & 6,165 & 5,639 & 3,095 & 671,105 & 1,375 & 13,819 \\
\hline $7 \mathrm{~b} 1$ & 681,931 & 9,382 & 8,703 & 5,001 & 410,726 & 1,929 & 21,164 \\
\hline $7 \mathrm{~b} 2$ & 455,035 & 5,836 & 5,258 & 1,783 & 260,378 & 1,804 & 11,031 \\
\hline Great Britain & $24,583,701$ & 631 & 2,386 & 1,372 & $13,901,282$ & 355 & 4,520 \\
\hline
\end{tabular}

Source: Wealth and Assets survey

* Refers to half the sample only 